\title{
Airborne and ground-based transient electromagnetic mapping of groundwater salinity in the Machile-Zambezi Basin, southwestern Zambia
}

Chongo, Mkhuzo; Vest Christiansen, Anders; Tembo, Alice; Banda, Kawawa Eddy; A. Nyambe, Imasiku; Larsen, Flemming; Bauer-Gottwein, Peter

Published in:

Near Surface Geophysics

Link to article, DOI:

10.3997/1873-0604.2015024

Publication date:

2015

Document Version

Peer reviewed version

Link back to DTU Orbit

Citation (APA):

Chongo, M., Vest Christiansen, A., Tembo, A., Banda, K. E., A. Nyambe, I., Larsen, F., \& Bauer-Gottwein, P. (2015). Airborne and ground-based transient electromagnetic mapping of groundwater salinity in the Machile-Zambezi Basin, southwestern Zambia. Near Surface Geophysics, 13(4), 383-396. https://doi.org/10.3997/1873-0604.2015024

\section{General rights}

Copyright and moral rights for the publications made accessible in the public portal are retained by the authors and/or other copyright owners and it is a condition of accessing publications that users recognise and abide by the legal requirements associated with these rights.

- Users may download and print one copy of any publication from the public portal for the purpose of private study or research.

- You may not further distribute the material or use it for any profit-making activity or commercial gain

- You may freely distribute the URL identifying the publication in the public portal 
Airborne and ground-based transient electromagnetic mapping of groundwater salinity in the Machile-Zambezi Basin, southwestern Zambia

Mkhuzo Chongo $^{1^{*}}$, Anders Vest Christiansen ${ }^{2}$, Alice Tembo ${ }^{3}$, Kawawa E. Banda ${ }^{1,4}$, Imasiku A Nyambe ${ }^{4}$, Flemming Larsen ${ }^{5}$ and Peter Bauer-Gottwein ${ }^{1}$

*Email: Mkhuc@env.dtu.dk

${ }^{1}$ Technical University of Denmark, Department of Environmental Engineering, Miljøvej, Building 113, 2800 Kgs. Lyngby, Denmark

${ }^{2}$ Aarhus University, Department of Geoscience, C.F. Møllers Alle 4, 8000-Århus C, Denmark

${ }^{3}$ University of Zambia, School of Mines, Integrated Water Resources Management Centre, Great East Road Campus, P.O. Box 32379, Lusaka, Zambia

${ }^{4}$ University of Zambia, School of Mines, Department of Geology, Great East Road Campus, P.O. Box 32379, Lusaka, Zambia

${ }^{5}$ Geological Survey of Denmark and Greenland (GEUS), Geochemistry, Øster Volgade 10, 1350 København K, Denmark

Received September 2014, revision accepted February 2015

\section{ABSTRACT}

The geological and morphological evolution of the Kalahari Basin of Southern Africa has given rise to a complex hydrogeological regime that is affected by water quality issues. Among these concerns is the occurrence of saline groundwater. Airborne and ground-based electromagnetic surveying is an efficient tool for mapping groundwater quality variations and has been used extensively to explore the Kalahari sediments, e.g., in Botswana and Namibia. Recently, airborne- and ground-based mapping of groundwater salinity was conducted in the Machile-Zambezi Basin, southwestern Zambia, using the versatile time-domain electromagnetic system and WalkTEM system, respectively, incorporating earlier groundbased ProTEM 47D measurements. The data were inverted using the laterally constrained inversion technique followed by a separate spatially constrained inversion scheme. WalkTEM data were inverted as ordinary single-site one-dimensional inversions. The regional electrical resistivity signature of the Machile-Zambezi Basin was found to be characterized by high elevation (1000 m-1050 m above mean sea level), high electrical resistivity (above $100 \Omega \mathrm{m}$ ) 
areas that form the western and eastern boundaries of a low-resistivity (below $13 \Omega \mathrm{m}$ ) valley that extends southwestwards into the Makgadikgadi salt pans. The electrical resistivity distribution is indicative of a full graben related to the Okavango-Linyati Fault system as a result of propagation of the East African Rift Valley System into Southern Africa. The saline lacustrine sediments infilling the Machile Graben are responsible for the low formation resistivity (below13 $\Omega \mathrm{m}$ ) and high salinity (above $7000 \mu \mathrm{S} / \mathrm{cm}$ ) observed in the groundwater and are probably related to the complex evolutionary history of Palaeo-Lake Makgadikgadi.

\section{INTRODUCTION}

The Kalahari sediments contain important groundwater resources throughout Southern Africa, which however are constrained by a very variable water quality. Much effort has been made to characterize the sediments and groundwater resources of the Kalahari Basin (Worthington 1977; Arad 1984; Thomas and Shaw 1993, 2002; McCarthy and Haddon 2005; McCarthy 2013), a basin which stretches from South Africa in the south into the Democratic Republic of Congo over a distance of $2200 \mathrm{~km}$ (McCarthy and Haddon 2005) to form an extensive sea of sand (Thomas and Shaw 1990). Geological events related to the breakup of Gondwana have had a major influence on the geological evolution and geomorphology of Southern Africa in general and the Kalahari Basin in particular (McCarthy 2013). This has been characterized by a series of tectonic, volcanic, fluvial, and aeolian processes over geological timescales. At the base of the simplified Kalahari stratigraphy is conglomerate sitting on pre-Kalahari formations. The conglomerate is in turn overlain by sandstone which in turn is overlain by the unconsolidated sands (Money 1972; McCarthy and Haddon 2005). The simplified stratigraphy exhibits local variations in terms of the presence or absence of lithological units. For example in places, the conglomerate is absent, and sandstone overlain by aeolian sands rests directly on the bedrock, whereas in others, mudstones and siltstones overlie the conglomerate before coarsening upwards into sandstone (McCarthy 2013). Figure 1 depicts the surface geology (unconsolidated sands) in the Okavango-Makgadikgadi-Machile area as being predominantly Cenozioic.

One way of addressing water quality concerns is to use the transient electromagnetic (TEM) method to identify water quality variations in potential aquifers (Melloul and Goldenberg 1997; Land et al. 2004; Ezersky et al. 2011). In the last few decades, TEM has been developed and used extensively around the globe to identify fresh water aquifers, delineate saltwater-freshwater interfaces, and map the spatial extent of salty groundwater (Guerin et al. 2001; Auken et al. 2003; Danielsen et al. 2007; Levi et al. 2008; Boucher et al. 2009; Bauer- 
Gottwein et al. 2010; Herckenrath 2012; Nenna et al. 2013). Large-scale airborne geophysical mapping in the Okavango Delta, conducted by the Government of Botswana, has played a major role in the understanding of the groundwater system of the Kalahari Basin (Campbell et al. 2006; Kgotlhang 2008; Podgorski et al. 2013a). Airborne and follow-up ground-based TEM data were used in these studies to map potential freshwater aquifers based on their relatively high formation electrical resistivities. Such aquifers appeared as sinuous zones of moderate resistivity in an otherwise low-resistivity environment. This reflected the widespread distribution of saline groundwater and, to a lesser extent, clay-rich units interbedded with the sands. The TEM data were used by Campbell et al. (2006) to set the lateral extent of potential freshwater aquifers as well as the fresh-saline water interface. Earlier work by Sattel and Kgotlhang (2004) in the Boteti area of Botswana used airborne TEM data collected with the TEMPEST system to map geological features that are consistent with the occurrence of fresh groundwater in the Palaeo-Lake Makgadikgadi system (Burrough et al. 2009). From this, they noted that freshwater occurred as recharge lenses above saline groundwater. Their correlation of TEM-derived resistivity depth profiles with borehole data showed that the resistivity of the Kalahari super-group lithology is defined by the level of clay content, amount of saturation, and pore water salinity. Using a numerical modelling approach, Bauer et al. (2006) reproduced the salinity distribution in and around the Shashe River Valley in Botswana by modelling transpiration as a function of groundwater salinity. The model results were in agreement with airborne and ground-based TEM data (including-water level data and geochemical evaluation). The Airborne TEM data clearly outlined fresh groundwater lenses resulting from infiltration of fresh surface water along stream channels into a stagnant saline aquifer in the interfluves. In addition, profiling with ground-based TEM across the Shashe River valley suggested the thickness of the freshwater lenses to be on the order of 60 $\mathrm{m}$ and to be superficially embedded in a highly saline aquifer (formation electrical resistivity between $0.5 \Omega \mathrm{m}$ and $5 \Omega \mathrm{m}$ ) with strong formation resistivity correlation to the total dissolved solids of the groundwater given the saturated conditions and relatively uniform sandy lithology (Bauer et al. 2006). In order to define the occurrence of salty groundwater in the Sesheke area in Zambia, Chongo et al. (2011) conducted single-site ground-based TEM measurements on a regional scale and showed that salty groundwater mainly occurs in a topographic depression east of Sesheke Town, which is related to faulting associated with the East African Rift Valley System (EARS) (McCarthy 2013). They further hypothesized that the origin of the salty groundwater was related to evapo-concentration of salts in inter-dune deposits and evaporation of the palaeo-Lake Makgadikgadi. The general layered Earth model 
from the TEM measurements indicated an unconfined freshwater aquifer with electrical resistivities in excess of $70 \Omega \mathrm{m}$ underlain by salty groundwater with resistivities below 35 $\Omega \mathrm{m}$. Podgorski et al. (2013a) described the Okavango Delta as an alluvial mega-fan and used airborne TEM data constrained by ground-based TEM seismic data and borehole records to provide additional evidence for an ancient large-scale alluvial fan complex underlying the Makgadikgadi sediments. Their airborne TEM data were a reprocessing of a commercially obtained versatile TEM (VTEM) data set from the Okavango Delta affected by systematic errors and with large uncertainties regarding key system parameters. This was the same type of VTEM system used for the airborne TEM survey in the Machile-Zambezi Basin for this study, and a number of steps were taken to retrieve the best possible results; given that the data collected was prone to contamination of early time gates by transmitter currents, noise in late time gates, and amplitude shifts between adjacent flight lines. Most importantly, accurate ground-based TEM data were used to calibrate the VTEM data in order to eliminate absolute amplitude inaccuracies and timing errors between receiver and transmitter instrumentation (Podgorski et al. 2013b). Contaminated early time and noisy late time gates were semiautomatically eliminated for each record.

Late Palaeogene uplift along the Okavango-Kalahari-Zimbabwe axis and associated subsidence of the Kalahari Basin disrupted the southwesterly flow of the Palaeo ChambeshiKafue-Upper Zambezi (PCKU) into the Indian Ocean via the proto-Limpopo River. This Palaeogene tectonism also resulted in the damming of the Cubango-Cuito (proto-Okavango River system) and Cuando rivers to form a closed fluvial/lacustrine Kalahari Basin (Moore et al. 2012). Headward erosion of the Mid-Zambezi led to the capture and diversion of the PCKU system to the Indian ocean via the lower Zambezi (Main et al. 2008). This was marked by a significant decrease in sedimentation in the Kalahari Basin between the Pliocene to Early Pleistocene (Moore et al. 2012). Secondary faulting related to the southwesterly development of the EARS through the Mweru-Tanganyika-Kabompo Gorge axis resulted in the Okavango-Linyati fault system responsible for formation of the Machile Graben bound to the northwest by the Sesheke fault and to the southeast by the Chobe/Mambova Fault (Fig. 1) (Moore et al. 2012; McCarthy 2013). Early Pleistocene uplift of the Chobe Horst and related subsidence of the Machile Graben redirected the flow of the PCKU system into the endorheic Kalahari Basin to result in the highest lake stand-palaeo-Lake Deception. This was later reduced to the 945-m level corresponding to the Palaeo-Lake Makgadikgadi following loss of the palaeo-Chambeshi River flow as a result of capture by the Luapula River initiated by 2.2 Ma-1.8 Ma uplift of the Congo-Zambezi Watershed (McCarthy 2013). 
The palaeo-Lake Makgadikgadi was maintained by flow from the Cubango-Cuito, Cuando, and Upper Zambezi-proto-Kafue rivers and associated climatic feedback (Moore et al. 2012). At this point, the proto-Kafue River still drained into the Upper Zambezi via the Machile Flats. Early to Mid-Pleistocene Uplift along the Machile-Kafue Watershed finally severed the link between the Upper Zambezi and the Proto-Kafue with consequent contraction of the palaeo-Lake Makgadikgadi to the 936-m shoreline. Incision of the Chobe Horst initiated during high lake stands by over topping maintained some flow in the Middle Zambezi, which in turn sustained riverine erosion and lead to the final breach at Mambova (Fig. 1) to establish the modern course of the Zambezi River in the Mid-Pleistocene. In addition, tectonic events reorganized the Okavango and Cuando river systems, resulting in reduced flow into the palaeo-Lake Makgadikgadi system that resulted in eventual drying up, leaving behind remnants such as the Makgadikgadi Salt Pans(Main et al. 2008; Burrough et al. 2009; Moore et al. 2012; McCarthy 2013). Thus, endorheic conditions were initiated in the Kalahari Basin in the Late Palaeogene (approximately $25 \mathrm{Ma}$ ) with subsequent formation of palaeo-Lake Makgadikgadi by Early Pleistocene (2.2 Ma-1.8 Ma). Early Mid-Pleistocene (more than 500 $\mathrm{Ka}$ ) isolation of the proto-Kafue from the Upper Zambezi initiated desiccation of palaeo-Lake Makgadikgadi until its final extinction in the Mid-Late Pleistocene $(100 \mathrm{Ka})$ to present (Moore et al. 2012).

The objectives of this study were to map for the first time the paleo-Lake Makgadikgadi sediments in the Machile flats of Zambia using airborne TEM methods, demonstrate the utility of TEM in the Machile-Zambezi geological setting for groundwater quality mapping, extend the regional coverage and spatial resolution of the work by Chongo et al. (2011) to encompass the entire Machile-Zambezi Basin using a combination of airborne and groundbased TEM measurements, and to come up with a consistent conceptual explanation for the observed electrical resistivity variations. This was necessary in order to shed more light on and gain a better understanding of the Palaeo-Lake Makgadikgadi system that extends into Zambia and in order to understand the occurrence of saline groundwater and how it relates to the geology. From a management perspective, this was also important because it will lead to improved access to clean drinking water in rural and remote areas though a better understanding of the groundwater regime, and quicker, efficient, and cost-effective means of evaluating groundwater for borehole placement.

\section{MATERIALS AND METHODS}

Description of the study area 
The Machile-Zambezi basin is located between latitude $16^{\circ}-17^{\circ} 54^{\prime} \mathrm{S}$ and longitude $24^{\circ} 13^{\prime}-$ $26^{\circ} 22^{\prime} \mathrm{E}$. It encompasses river basins for the three main northerly tributaries of the Zambezi, namely, Loanja, Machile, and Ngwezi, and a number of other smaller river basins. The outlet to the Machile-Zambezi Basin is defined at $17^{\circ} 50.4^{\prime} \mathrm{S}$ and $25^{\circ} 38^{\prime} \mathrm{E}$ (Fig. 2) and is therefore hydrologically defined but encompasses the northern tip of the Makgadikgadi Basin that extends into Zambia, which is called the Machili Basin by Moore and Larkin (2001) (Fig. 2). The dominant surface geology is unconsolidated sediments of Cenozoic Era with outcrops of basaltic and basement rocks in places particularly in the eastern areas where the presence of basement complex rocks is significant. The topography is characterized by a valley that is widest in the south central areas and narrows towards the northeast with elevations ranging between $800 \mathrm{~m}$ and $1200 \mathrm{~m}$ above mean sea level (amsl) (Fig. 2).

\section{Transient electromagnetic (TEM) method}

Based on the principles of electromagnetism, secondary currents can be induced in the subsurface by a time-varying electromagnetic field. The secondary magnetic fields generated by the secondary currents can then be measured by appropriate electromagnetic receivers (Nabighian 1988). The two main types of electromagnetic prospecting are frequency-domain electromagnetic (FEM) methods and time-domain (or transient) electromagnetic (TEM) methods (Nabighian 1988; Nabighian 1991; Kirsch 2006). TEM methods were used for this research. These comprised both ground-based and airborne measurements. Airborne TEM measurements were conducted with the helicopter-borne VTEM system developed by Geotech Limited who were contracted by the Ministry of Energy and Water Development (MEWD) of the Republic of Zambia to conduct the survey (Geotech 2011). Ground-based TEM measurements were carried out with the WalkTEM system (ABEM(B) 2014) developed by Aarhus University and ABEM Instrument AB. In both cases, a central loop configuration was used. The VTEM system had a nominal terrain clearance of $48 \mathrm{~m}$ and nominal flight speed of $90 \mathrm{~km} / \mathrm{h}$, and a total of 1000 line kilometres were flown. This comprised two sets of four parallel lines as shown in Fig. 2. One set was southwest to northeast trending and the other northwest to southeast trending. In both instances, the line separation was $2000 \mathrm{~m}$. The 24 ground-based TEM soundings were conducted on the eastern side of the Machile River. These, together with the 66 TEM soundings conducted by Chongo et al. (2011) and the 27 soundings collected for calibration form the ground-based TEM data set for this paper (Fig. 2). The total number of TEM soundings collected for the Machile-Zambezi Basin was 
therefore 117 soundings over $26260 \mathrm{~km}^{2}$. Field schematics, transmitter waveform and system response of both the airborne and ground-based deployment are illustrated in Fig. 3. A central loop configuration was used for the VTEM setup with concentric transmitter and receiver coils. The outer loop in the form of a 12-sided polygon acted as the transmitter loop with a diameter of $26 \mathrm{~m}$ and four turns transmitting a peak current of $240 \mathrm{~A}$. The inner loop had a diameter of $1.2 \mathrm{~m}$ and 100 turns and acted as the receiver coil (Geotech 2011) (Fig. 3a). The WalkTEM system also used the central loop configuration with a single-turn $40 \mathrm{~m}$ by 40 m transmitter loop and a $0.5 \mathrm{~m}$ by $0.5 \mathrm{~m}$ receiver coil in the centre with 20 internal turns(ABEM(b) 2014) (Fig. 3b). The VTEM transmitter current waveform is $4.7 \mathrm{~ms}$ long with a peak at $-1.646 \mathrm{~ms}$. Receiver gates commence shortly after the transmitter turns off at $0 \mathrm{~ms}$ with gate widths progressively increasing at later times. Gate centre times start at $21 \mu$ s and end at $10667 \mu$ s with a total of 45 gates (Fig. 3c). The WalkTEM system had two waveforms: a high-moment waveform transmitting a 10-ms 8-A pulse and a low-moment waveform with amplitude of $1 \mathrm{~A}$ and duration of $10 \mathrm{~ms}$. Turn-off time was $5.9 \mu \mathrm{s}$ and $10.4 \mu \mathrm{s}$ for low and high moments, respectively. The low-moment response was measured over 23 gates with the first gate centre time at $3.6 \mu$ s and the last gate centre time at $364 \mu$ s. The high moment response was measured over 37 time gates with the first gate centre time position at $3.6 \mu \mathrm{s}$ and the last at $8850 \mu \mathrm{s}$. The low moment is optimized for early time gate measurements and thus near surface geological information, whereas the high moment is optimized for later time gate measurements and thus deeper surface geological information (Fig. 3d).

\section{Aerial survey}

The instrumentation for the airborne survey was mounted on an AS 350 B3 helicopter equipped with a Terra TRA 3000/ TRI40 radar altimeter and a NovAtel wide-areaaugmentation-system-enabled OEM4-G2-3151W GPS navigation system with a sampling interval of $0.2 \mathrm{~s}$. The TEM transmitter and receiver loops were carried as a sling load beneath the helicopter with a sampling interval at $0.1 \mathrm{~s}$. The VTEM decay sampling scheme was configured for 45 time gates. The first gate centre time was at $21 \mu \mathrm{s}$, and the last gate centre time was at $10.667 \mathrm{~ms}$ (Geotech 2011). The transmitter current waveform and receiver time gates are illustrated in Fig. 3c. Electromagnetic data collected for the survey were presented as $d b / d t$ (time derivative of magnetic flux through the receiver coil). The data were imported into the Aarhus workbench (HGG 2014) where they were processed and inverted. The processing performed in the workbench was on data that were already pre-processed by Geotech (2011) using an undocumented three-stage digital filtering process to reject major 
broadband electromagnetic impulses or spherics caused by lightening events and to reduce system noise. The signal-to-noise ratio was further improved by the application of a low-pass linear digital filter, but the characteristics of this filter and its effects on the data were not documented by Geotech (2011). Thus the uncertainties about how the digital filtering was conducted by Geotech (2011) in addition to transmitter-receiver timing errors and amplitude shifts necessitated calibration of the airborne TEM data set with accurate ground-based TEM measurements (Podgorski et al. 2013b) in order to obtain a more reliable inversion and interpretation. Interpretation of resistivity data obtained from TEM measurements is described in more detail in the Discussion section.

\section{Ground survey}

The ground-based TEM data set comprised data from both ProTEM and WalkTEM equipment. The ProTEM equipment was set to measure at three different repetition rates under the 20-gate mode. The repetition rates were designated as $u(237.5 \mathrm{~Hz}), v(62.5 \mathrm{~Hz})$, and $H(25 \mathrm{~Hz})$, and the current was set at 3 A throughout with a standard square transmitter waveform characteristic of the ProTEM equipment. Thus, for each location, a complete sounding comprised one measurement for each of the three repetition rates. The gate times for the $u$ repetition rate were optimized for early times, whereas those for the $H$ repetition rate were optimized for late times. The repetition rate $v$ had an overlap between the gate times for the $u$ and $H$ repetition rates. The WalkTEM equipment used the concept of low moment and high moment. For each sounding, one measurement was made with the current setting at $1 \mathrm{~A}$ (low moment) and another with the current setting at $8 \mathrm{~A}$ (high moment). Figure 3d illustrates the concept of low and high moments used by the WalkTEM equipment. The low moment is optimized for early times, and the high moment is optimized for late times. Characteristics of the transmitter waveforms and receiver gate times were all controlled through user-defined script files. The location of the ground-based TEM soundings for the Machile-Zambezi Basin are shown in Fig. 2. Each sounding was inverted individually using AarhusInv (Auken and Christiansen 2007; Auken et al. 2014) and the best-fit model with residuals below 1 that made geologic and physical sense was selected as the most appropriate at that location.

\section{Inversion methodology}

Inversion of the airborne data set from the time derivative of the secondary electromagnetic field $(d b / d t)$ passing through the receiver coil to resistivity layered Earth models was done using two separate but similar techniques. These are laterally constrained inversion (LCI) 
(Auken et al. 2005) and spatially constrained inversion (SCI) (Viezzoli et al. 2008). Using the LCI technique, each of the eight flight lines was inverted individually segment by segment. A typical flight line comprised two or three segments, and with the SCI technique, all flight lines were inverted together as one inversion job. In both cases, tight constraints were set on a smooth or minimum-structure starting model, given the relatively homogeneous sedimentary terrain. Thus, a 29-fixed-layer starting model was setup such that the mean apparent resistivity for each sounding was used as the initial resistivity for each layer. No a priori information was added. The thickness of the first layer was $7 \mathrm{~m}$ and that of the last layer was 60 m, i.e., the thicknesses increased progressively with depth. Vertical and lateral reference constraints on resistivity values were set to 2.5 and 1.3, respectively. The reference distance for the reference constraints was set to $25 \mathrm{~m}$ with the with the power law factor (Christiansen et al. 2007) set to 0.5 .

\section{Calibration of the airborne data set}

High-quality ground-based TEM soundings that were coincident with the airborne TEM data within a distance of $50 \mathrm{~m}$ were used for calibration, and in total, these were 14 soundings. At each of the 14 sites, a forward response based on the layered Earth model from inversion of the ground-based TEM sounding was compared with the corresponding VTEM sounding at the same location. A manual calibration was then conducted by first shifting the VTEM sounding curve vertically upwards to get the level right and then horizontally to get the time shift right. The amount of vertical and horizontal shift comprised the calibration parameters designated as shift factor and time shift, respectively. The procedure and considerations used for processing and calibration of the airborne data set are similar to those of Podgorski et al. (2013b) who report a final time shift of $30 \mu$ s and a final shift factor of 1.44. For this study, the time shift was determined as $-44.929 \pm 10.05 \mu \mathrm{s}$, and the shift factor was determined as $1.071 \pm 0.112$ based on averaging of the calibration results at 14 sites. The difference in sign between the time shift factor reported by Podgorski et al. (2013b) and the one determined in this study probably has to do with the amount of system drift experienced by the respective VTEM systems used at each survey. The calibration was thus completed by subtracting $44.929 \mu$ s from all time gates and multiplying all raw data values $(d b / d t)$ with 1.071.

A qualitative assessment of the effect of calibration on the inversion was conducted by comparing the inversion result from an LCI with uncalibrated data (Fig. 4a) to that of a similar LCI with calibrated data (Fig. 4b) and another also with calibrated data but using SCI (Fig. 4c). 


\section{RESULTS}

The results from the airborne and ground-based TEM surveys are presented below as maps and cross sections.

The mean horizontal electrical resistivity map (Fig. 5) at depth interval of $0 \mathrm{~m}-20 \mathrm{~m}$ was superimposed over the topography in the Machile-Zambezi Basin and depicts low electrical resistivity values (1-10 $\Omega \mathrm{m}$ ) confined to the low lying south central region. At higher elevation particularly in the northeastern and northwestern regions, the electrical resistivity values are very high in the range of $1000 \Omega \mathrm{m}$. In between and surrounding the high and low electrical resistivity blocks are areas of moderate values (10 $\Omega \mathrm{m}$ to $100 \Omega \mathrm{m}$ ).

The mean horizontal electrical resistivity map at $80 \mathrm{~m}-100 \mathrm{~m}$ (Fig. 6) is similar to that at $0 \mathrm{~m}$ to $20 \mathrm{~m}$ (Fig. 5 above), except that the south central low-resistivity region is smaller in spatial extent and roughly coincides with the 945-m contour. In addition, the western and eastern areas with high resistivities are larger and elongated from southwest to northeast. North of the area with low electrical resistivity oriented towards the north east is an elongated moderate resistivity region that, together with the low resistivity block, appears to be in a valley structure between the western and eastern electrical resistivity blocks.

The electrical resistivity structure along the northwest to southeast profile (Fig. 7a) indicates a low lying area with low electrical resistivity in the centre bound by an area with high electrical resistivity to the west (left hand side) and another area with high electrical resistivity to the east (right hand side) (Fig. 7a). The low electrical resistivities are interrupted in the shallow subsurface by moderate resistivity anomalies. Along the southwest to northeast profile line, a low resistivity or high conductivity region shaped in form of a pot with a handle extends from south (left hand side) to north (right hand side) with the pot handle pinching out towards the north. Underlying the pot handle is the moderate resistivity region, which crops out in the northern areas. The main low resistivity pot is interrupted in the southern shallow subsurface by moderate anomaly resistivity values ranging from $10 \Omega \mathrm{m}$ to $100 \Omega \mathrm{m}$ (Fig. 7b). Evaluation of borehole log data from various boreholes in the Sesheke area formed a basis of inferring groundwater salinity from the electrical resistivity mapped by TEM. An example borehole $\log$ at borehole RV31 (borehole number 1 in Table 1 below) is shown in Fig. 8, whereas the location of the borehole logs considered are shown in Figs. 5 and 6 above.

From the borehole logs, formation factors (Tsallis et al. 1992; Neretnieks et al. 2001) were determined using the pore water resistivity (which was measured as fluid conductivity with the borehole probe in $\mu \mathrm{S} / \mathrm{cm}$ ) and formation resistivity below the water table (which was 
measured as long conductivity in $\mathrm{mS} / \mathrm{m}$ with an induction probe). The construction of most boreholes implemented a screen interval from the water table up to $3 \mathrm{~m}$ above the bottom of the borehole. A single formation factor was thus assigned to each borehole by calculating the average formation factor from individual entries in the borehole log, and the nominal formation resistivity around each borehole was defined as the product of the average pore water resistivity and the borehole formation factor. The formation factors and formation electrical resistivity values calculated for each borehole are shown in Table 1.

Also shown in Table 1 are formation resistivity thresholds of groundwater salinity, below which the groundwater is considered salty and above which it is considered freshwater or non-saline water. The formation resistivity thresholds were calculated by multiplying the respective formation factor with the threshold for non-saline water, which was taken as 700 $\mu \mathrm{S} / \mathrm{cm}$ or $14.3 \Omega \mathrm{m}$ (FAO 2014). This implies that, in areas with very high clay content (i.e., high surface electrical conductivity), electrical resistivity values below $12.6 \Omega \mathrm{m}$ are indicative of salty groundwater, whereas in areas with very little clay content, the threshold is at 75.3 $\Omega \mathrm{m}$. This high degree of variability of formation factors is probably a consequence of the different geological domains from which the respective borehole logs were sampled, but the values are typical of what can be expected in sedimentary terrain comprising mostly clay, sand, and sandstone (Salem 2001). Similarly, the formation factor for the Machile-Zambezi Basin varies around $3.08 \pm 2.19$.

\section{DISCUSSION}

Overall, the resistivity structure mapped by TEM in the Machile-Zambezi Basin (Fig. 6) is characterized by three southwest to northeast trending areas of distinct electrical resistivity. These are:

(i) the westerly high-electrical-resistivity area with resistivity values greater than $100 \Omega$;

(ii) the middle area with low to moderate electrical resistivity (with values less than 100 $\Omega \mathrm{m})$, which is further subdivided into the south central area with low electrical resistivity and the central, southwest to northeast trending area with moderate electrical resistivity area;

(iii) the easterly high electrical resistivity area with resistivity values greater than $100 \Omega \mathrm{m}$.

The high-resistivity structure of the westerly block is attributed to a typical Kalahari Basin stratigraphy (McCarthy and Haddon 2005) of unconsolidated sands underlain by sandstone or basalt. A borehole profile at Munyeula (Kameyama 2003) (Borehole 3 in Table 2) reveals a 
$12 \mathrm{~m}$ sequence of sand underlain by a 58-m succession of sandstone, which in turn overlies weathered and fractured Batoka Basalt. The electrical conductivity recorded in the groundwater from this borehole is $263 \mu \mathrm{S} / \mathrm{cm}$. This shows consistency between the formation resistivity measured by the TEM methods and the intrinsic high resistivity of the unconsolidated sands, sandstone, basalt, and pore water at this location. The borehole record at Munyeula also shows the water table to be $4.4 \mathrm{~m}$, implying that a $4.4 \mathrm{~m}$ sequence of dry Kalahari sand sits on top of the water table and would typically register as a high-resistivity layer with resistivity values greater than $500 \Omega \mathrm{m}$. Below the water table, the resistivity values would be moderated downwards to below $100 \Omega \mathrm{m}$ until solid bed rock is encountered; at which point, they would also register high resistivity values in the $1000 \Omega \mathrm{m}$ order of magnitude. Similarly, the surface geology of the easterly block is defined in the northeast by a southwest to northeast trending basement complex (Pre Cambrian geology) region and in the southwest by what appears to be a basin filled with Kalahari sediments and bound to the northeast and southwest by Mesozoic igneous horsts (see Fig. 2 above) herein referred to as the Sekute Basin. A borehole record at Siamundele (Bäumle et al. 2007) (Borehole 4 in Table 2) indicates a granitic formation consistent with the high formation resistivity detected by the TEM methods. In addition, a borehole record at Sekute School (Bäumle et al. 2007) (Borehole 5 in Table 2) indicates that the stratigraphy of the Sekute Basin is characterized by sand and clay $(6 \mathrm{~m})$ on top of sandstone $(18 \mathrm{~m})$, which in turn is underlain by basalt, a lithology log similar to the borehole profile at Munyeula in the easterly block, and a similar relationship to the formation resistivity measured by the TEM methods is thus inferred. A summary of selected borehole records in the Sesheke and Kazungula areas of Southwestern Zambia in the three resistivity blocks of the Machile-Zambezi Basin is shown in Table 2.

The electrical resistivity structure of the middle area as aforementioned has two sub-divisions. The first one is the south and central low-electrical-resistivity area that has an extent closely following the 945-m contour synonymous with the Palaeo-Lake Makgadikgadi shoreline (Fig. 5 above). However, the spatial extent of the low-electrical-resistivity area is much larger at shallower depths (Fig. 5 above) and extends northeasterly beyond the 945-m contour by about $32 \mathrm{~km}$ with a vertical rise of about $20 \mathrm{~m}$. The low resistivity block therefore overlies and thins out into the southwest to northeast trending moderate resistivity block northeast of the 945-m contour. The moderate resistivity block is abruptly truncated in the vicinity of the 945-m contour and has a gentle rise towards the northeast until it overlies the thinning-out lowelectrical-resistivity area (Fig. 7b above). Existence of the low-resistivity block can be attributed to sediments related to the Palaeo-Lake Makgadikgadi with evidence of this 
correlation arising from the borehole profiles at Kasaya and Mbanga (Table 2). These depict alternating and mixed sequences of fine sand and clay with very high pore-water salinity; 7250 and $12180 \mu \mathrm{S} / \mathrm{cm}$ at Mbanga and Kasaya (boreholes 1 and 2 in Table 2). Milzow et al. (2009) observed a similar setting in the Okavango Delta and attributed the alternating and mixed sequences of clay and sand to alternating cycles of fluvial and lacustrine depositional setting. The work by Banda et al. (Technical University of Denmark/University of Zambia, Unpublished data, 2014) used borehole logging, sediment core characterization, and geochemical analysis to postulate that Palaeo-Lake Makgadikgadi sediments were responsible for groundwater salinity in the Machile Basin (after Moore and Larkin (2001)), which is congruent with the low-electrical-resistivity area. Banda et al. (Technical University of Denmark/University of Zambia, Unpublished data, 2014) thus describe a lithological setting of alternating and mixed sequences of silty clay, clay, and sand attributed to fluvial and lacustrine deposition associated with varying climatic conditions containing saline groundwater entrapped at the time of deposition of the lake sediments. In addition, the fact that the low-electrical-resistivity area closely follows the $945 \mathrm{~m}$ contour at the depth interval of $80 \mathrm{~m}-100 \mathrm{~m}$ is further supporting evidence of Palaeo-Lake Makgadikgadi sediments in the Machile-Zambezi Basin. However, this is in contrast to the extension of the low-resistivity area beyond the $945 \mathrm{~m}$ contour towards the northeast for depth interval of 0 to $20 \mathrm{~m}$ (refer to Fig. 5 above). A possible explanation for this is likely related to uplift along the KafueMachile Watershed and associated closure of the palaeo-Kafue/Upper Zambezi link (McCarthy 2013). Alternatively, this could also be as a result of shallow groundwater related to the Palaeo-Lake Makgadikgadi, which was subjected to evapo-concentration.

According to Moore et al. (2012), the palaeo-Chambeshi River, which was a combination of the proto-Kafue and proto-Chambesh river systems, used to flow in to the Makgadikgadi Basin through the Machile Flats, where it would join the Upper Zambezi River. This southwesterly flow of the palaeo-Chambeshi was associated with deposition of Kalahari super-group sediments (Moore and Larkin 2001), which correlated with the Barotse sand member (Money 1972). Thus the deposition of sandstone is believed to have occurred in braided streams (McCarthy and Haddon 2005) indicative of low slope terrain, which could have easily been below or at the level of the $945 \mathrm{~m}$ contour by the time the sands were fully deposited. Lake sediments would have then been deposited in a shallow stretch up to the present northern extent of the low resistivity block followed by uplift along the KafueMachile Watershed (Moore et al. 2012). This uplift could have given rise to the gentle northeasterly slope responsible for occurrence of part of the low-resistivity block above the 
945-m contour. However, Banda et al. (Technical University of Denmark/University of Zambia, Unpublished data, 2014) postulate that this was probably the result of evapoconcentration of shallow groundwater from the palaeo-lake system. A borehole record at Kamenyani (Borehole 6 in Table 2) reveals an uppermost 4-m thick layer of fine sand overlying a 6-m sequence of clay. The clayey sequence is in turn underlain by a 22-m sequence of silt and sand suggestive of a lacustrine setting. The uppermost 4-m layer of sand is probably as a result of recent deposition by aeolian processes. The silt and sand sequence is underlain by sandstone. One implication of this interpretation is that the moderate resistivity area could have had resistivity values as low as in the low-electrical-resistivity area. However uplift along the Kafue-Machile Watershed resulted in a net groundwater flow towards the southwest, resulting in flushing of the system with fresh groundwater resulting in moderated electrical conductivity values such as the $1932 \mu \mathrm{S} / \mathrm{cm}$ observed at Kamenyani compared with the $12180 \mu \mathrm{S} / \mathrm{cm}$ observed at Kamenyani.

\section{CONCLUSION}

The resistivity structure of the Machile-Zambezi Basin is characterized by three distinct southwest-to-northeast trending electrical resistivity areas. These are:

(i) the high-electrical-resistivity westerly area with resistivity values greater than $100 \Omega \mathrm{m}$ associated with a sand, sandstone, and basalt downward sequence;

(ii) The middle low-to-moderate-electrical-resistivity area with values less than $100 \Omega \mathrm{m}$. This is further subdivided into the south and central low-electrical-resistivity area (with values less than $13 \Omega \mathrm{m}$ ) and the southwest-to-northeast trending moderateelectrical-resistivity area (with values between $10 \Omega \mathrm{m}$ and $100 \Omega \mathrm{m}$ ). The lowelectrical-resistivity area is congruent with the northern tip of the Palaeo-Lake Makgadikgadi sediments extending into southwestern Zambia and is filled with saline groundwater trapped at the time of deposition of the sediments;

(iii) the easterly high-resistivity block with resistivity values greater than $100 \Omega \mathrm{m}$ associated with Basement Complex and Kalahari stratigraphic settings.

The southwest to northeast orientation of the resistivity blocks is a clear indication of continuity of the Okavango-Linyati Fault System and associated Palaeo-Lake Makgadikgadi into southwestern Zambia.

The combination of ground-based and airborne TEM methods was thus effective in mapping the regional electrical resistivity structure of the Machile-Zambezi Basin 
from which groundwater salinity variations could be inferred in addition to the regional tectonic structure or geological fault system. Calibration of VTEM data with accurate ground-based WalkTEM data ensured a strong agreement between the airborne TEM inverted using an SCI scheme and ground-based data inverted as singlesite 1D inversions.

\section{ACKNOWLEDGEMENTS}

The authors would like to thank the governments of the Kingdom of Denmark and the Republic of Zambia for funding this research under the capacity building initiative for the Zambian Water Sector through the University of Zambia Integrated Water Resources Management Centre (UNZA IWRM); the Hydro-Geophysics Group of Aarhus University for assistance in processing and inversion of the airborne data set; their colleagues and friends who assisted in the fieldwork, particularly Kebby Kapika (District Water Officer-Sesheke) and Mweemba Sinkombo (District Water Officer-Nalolo) who was then a post-graduate diploma student at UNZA; and Ms. Ingrid Mugamya Kawesha of UNZA IWRM Centre for the logistical support.

\section{REFERENCES}

ABEM(B). 2014. WalkTEM User's Guide. ABEM Geophysics, Stockholm, Sweden.

Arad A. 1984. Relationship of salinity of groundwater to recharge in the southern kalahari desert. Journal of Hydrology 71, 225-238.

Auken E. and Christiansen A.V. 2007. Manual for the Inversion Programme em1dinv. In: GROUP, H. 5th edn. Hydrogeophysics Group, University of Aarhus, Aarhus, Denmark.

Auken E., Christiansen A.V., Jacobsen B.H., Foged N. and Sorensen K.I. 2005. Piecewise 1D laterally constrained inversion of resistivity data. Geophysical Prospecting 53, 497-506. Auken E., Christiansen A.V., Kirkegaard C., Fiandaca G., Schamper C., Behroozmand A.A. et al. 2014. An overview of a highly versatile forward and stable inverse algorithm for airborne, ground-based and borehole electromagnetic and electric data. Exploration Geophysics. (in press)

Auken E., Jørgensen F. and Sørensen K.I. 2003. Large scale TEM Investigations for groundwater. Exploration Geophysics 34, 88-194.

Bauer-Gottwein P., Gondwe B.N., Christiansen L., Herckenrath D., Kgotlhang L. and Zimmermann S. 2010. Hydrogeophysical exploration of three-dimensional salinity anomalies with the time-domain electromagnetic method (TDEM). Journal of Hydrology 380, 318-329. 
Bauer P., Held R.J., Zimmermann S., Linn F. and Kinzelbach W. 2006. Coupled flow and salinity transport modelling in semi-arid environments: The Shashe River Valley, Botswana. Journal of Hydrology 316, 163-183.

Bäumle R., Neukum C., Nkhoma J. and Silembo O. 2007. Groundwater resources of southern province (phase 1) annex 3 GReSP borehole data. In: Ministry of Energy And Water Development. Department of Water Affairs, Lusaka, Zambia.

Boucher M., Favreau G., Descloitres M., Vouillamoz J.-M., Massuel S., Nazoumou Y. et al. 2009. Contribution of geophysical surveys to groundwater modelling of a porous aquifer in semiarid Niger: An overview. Comptes Rendus Geoscience 341, 800-809.

Burrough S.L., Thomas D.S.G. and BAILEY R.M. 2009. Mega-Lake in the Kalahari: A Late Pleistocene record of the palaeolake Makgaikgadi system. Quaternary Science Reviews 28, 1392-1411.

Campbell G., Johnson S., Bakaya T., Kumar H. and Nsatsi J. 2006. Airborne geophysical mapping of aquifer water quality and structural controls in the Lower Okavango Delta, Botswana. South African Journal of Geology 109, 475-494.

Chongo M., Wibroe J., Staal-Thomsen K., Moses M., Nyambe, I.A., Larsen, F. et al. 2011. The use of time domain electromagnetic method and continuous vertical electrical sounding to map groundwater salinity in the Barotse sub-basin, Zambia. Physics and Chemistry of the Earth 36, 798-805.

Christiansen A.V., Auken E., Foged N. and Sorensen K.I. 2007. Mutually and laterally constrained inversion of CVES and TEM data: a case study. Near Surface Geophysics 5, 115123.

Danielsen J.E., Dahlin T., Owen R., Mangeya P. and Auken E. 2007. Geophysical and hydrogeologic investigation of groundwater in the Karoo stratigraphic sequence at sawmills in Nothern Matebeleland, Zimbabwe: a case history. Hydrogeology Journal 15, 945-960.

Ezersky M., Legchenko A., Al-zoubi A., Levi E., Akkawi E. and Chalikakis K. 2011. TEM study of the geoelectrical structure and groundwater salinity of the Nahal Hever sinkhole site, Dead Sea shore, Israel. Journal of Applied Geophysics 75, 99-112.

FAO. 2014. The Use of Saline Waters for Crop Production [Online]. Food and Agricultural Organisation, Natural Resources Management and Environment Department.

Geotech 2011. Survey and Logistics Report on a Helicopter Borne Versatile Time Domain Electromagnetic Survey on the Zambezi River Basin Kazungula Zambia for Ministry of Energy and Water Development (Republic of Zambia). Geotech Airborne Limited. 
Guerin R., Descloitres M., Coudrain A., Talbi A. and Gallaire R. 2001. Geophysical surveys for identifying saline groundwater in the semi-arid region of the central Altiplano, Bolivia. Hydrological Processes 15, 3287-3301.

Herckenrath D. 2012. Informing Groundwater Models with Near-Surface Geophysical Data. Technical University of Denmark, Lyngby, Denmark.

HGG. 2014. Aarhus Workbench [Online]. Aarhus University: Hydrogeophysics Group. Available: http://hgg.au.dk/software/aarhus-workbench/ [Accessed 30-06-2014 2014].

Kameyama N. 2003. Completion Report: JICA Borehole Drilling Project-Sesheke. Ministry of Energy and Water Development, Lusaka, Zambia.

Kgotlhang L.P. 2008. Application of airborne geophysics in large scale hydrological mapping; Okavango Delta, Botswana. Ph.D. doctoral and habilitation thesis, ETH Zurich. Kirsch R. (ed.) 2006. Groundwater Geophysics, A Tool for Hydrogeology. Springer, Flintbek, Germany.

Land L.A., Lautier J.C., Wilson N.C., Chianese G. and Webb S. 2004. Geophysical monitoring and evaluation of coastal plain aquifers. Ground Water 42, 59-67.

Levi E., Goldman M., Hadad A. and Gvirtzman H. 2008. Spatial delineation of groundwater salinity using deep time domain electromagnetic geophysical measurements: a feasibility study. Water Resources Research 44.

Main M.P.L., Moore A.E., Williams H.B. and Cotterill F.P.D. 2008. The Zambezi River. Large Rivers: Geomorphology and Management, 311-332.

Mccarthy T.S. 2013. The okavango delta and its place in the geomorphological evolution of

Mccarthy T.S. and Haddon I.G. 2005. The Mesozoic-Cenozoic interior sag basins of central Africa: the late Cretaceous-Cenozoic Kalahari and Okavango basins. Journal of African Earth Sciences 43, 316-333.

Melloul A.J. and Goldenberg L.C. 1997. Monitoring of seawater intrusion in coastal aquifers: basics and local concerns. Journal of Environmental Management 51, 73-86.

Milzow C., Kgotlhang L., Bauer-Gottwein P., Meier P. and Kinzelbach W. 2009. Regional review: the hydrology of the Okavango Delta, Botswana-processes, data and modelling. Hydrogeology Journal 17, 1297-1328.

Money N.J. 1972. An outline of the geology of Western Zambia. In: Records of the Geological Survey, Vol. 12 (eds A.R. Drysdall and R.L. Johnson). Geological Survey Department, Lusaka, Zambia. 
Moore A.E., Cotterill F.P.D. and Eckardt F.D. 2012. The evolution and ages of Makgadikgadi Palaeo-Lakes: consilient evidence from Kalahari drainage evolution South-Central Africa. South African Journal of Geology 115, 385-413.

Moore A.E. and Larkin P.A. 2001. Drainage evolution in south-central Africa since the breakup of Gondwana. South African Journal of Geology 104, 47-68.

Nabighian M.N. 1988. Electromagnetic Methods in Applied Geophysics, Vol 1.

Nabighian M.N. 1991. Electromagnetic Methods in Applied Geophysics, Vol. 2.

Nenna V., Herckenrath D., Knight R., Odlum N. and Mcphee D. 2013. Application and evaluation of electromagnetic methods for imaging saltwater intrusion in coastal aquifers: Seaside Groundwater Basin, California. Geophysics 78.

Neretnieks I., Ohlsson Y. and Löfgren M. 2001. Formation factor determinations by in-situ resistivity logging. Materials Research Society Symposium - Proceedings 663, 1197-1205.

Podgorski J., Auken E., Schamper C., Vest Christiansen A., Kalscheuer T. and Green A. 2013b. Processing and inversion of commercial helicopter time-domain electromagnetic data for environmental assessments and geologic and hydrologic mapping. Geophysics 78, E149E159.

Podgorski J.E., Green A.G., Kgotlhang L., Kinzelbach W.K.H., Kalscheuer T., Auken E. et al. 2013a. Paleo-megalake and paleo-megafan in southern Africa. Geology 41.

Salem H.S. 2001. Determination of porosity, formation resistivity factor, Archie cementation factor, and pore geometry factor for a glacial aquifer. Energy Sources 23, 589-596.

Sattel D. and Kgotlhang L. 2004. Groundwater exploration with AEM in the Boteti area, Botswana. Exploration Geophysics 35, 147-156.

Thomas D.S.G. and Shaw P.A. 1990. The deposition and development of the Kalahari Group sediments, Central Southern Africa. Journal of African Earth Sciences (and the Middle East) 10, 187-197.

Thomas D.S.G. and Shaw P.A. 1993. The evolution and characteristics of the Kalahari, Southern Africa. Journal of Arid Environments 25, 97-108.

Thomas D.S.G. and Shaw P.A. 2002. Late Quaternary environmental change in central southern Africa: new data, synthesis, issues and prospects. Quaternary Science Reviews 21, $783-797$.

Tsallis C., Curado E.M.F., Desouza M.D., Elias V.L., Bettini C., Scuta M.S. et al 1992. Generalized Archie law - application to petroleum reservoirs. Physica A 191, 277-283.

Viezzoli A., Christiansen A.V., Auken E. and Sorensen K. 2008. Quasi-3D modeling of airborne TEM data by spatially constrained inversion. Geophysics 73. 
610 Worthington P.F. 1977. Geophysical investigations of groundwater resources in the 611 KALAHARI basin. Geophysics 42.

612

613

614

615

616

617

618

619

620

621

622

623

624

625

626

627

628

629

630

631

632

633

634

635

Figure captions 


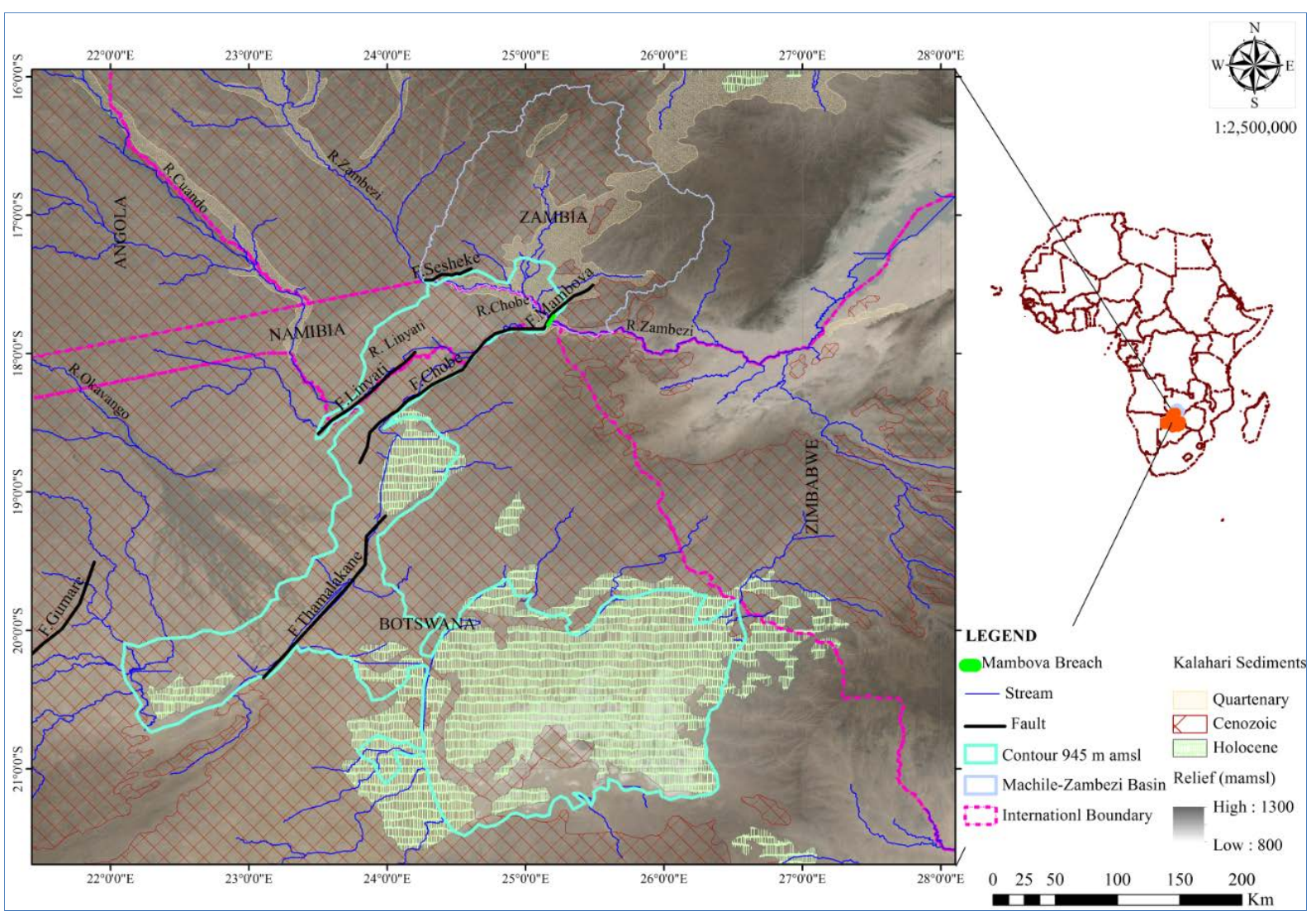

\section{Figure 1}

638 Contour (945-m amsl) corresponding to the Palaeo-Lake Makgadikgadi shoreline in Southern 639 Africa. In the background is the topography and Cenozoic surface geology corresponding to 640 the extent of the unconsolidated Kalahari sediment. Also depicted are various faults in the 641 Okavango-Machile depression here collectively referred to as the Okavango-Linyati Fault 642 System (Moore et al. 2012; McCarthy 2013) and the outline of the Machile-Zambezi Basin. 643 Data sources: Geological data-Persits et al. (http://pubs.usgs.gov/of/1997/ofr-97-470/OF97470A/, 2002), and elevation data-Jarvis et al. (http://srtm.csi.cgiar.org, 2008). 


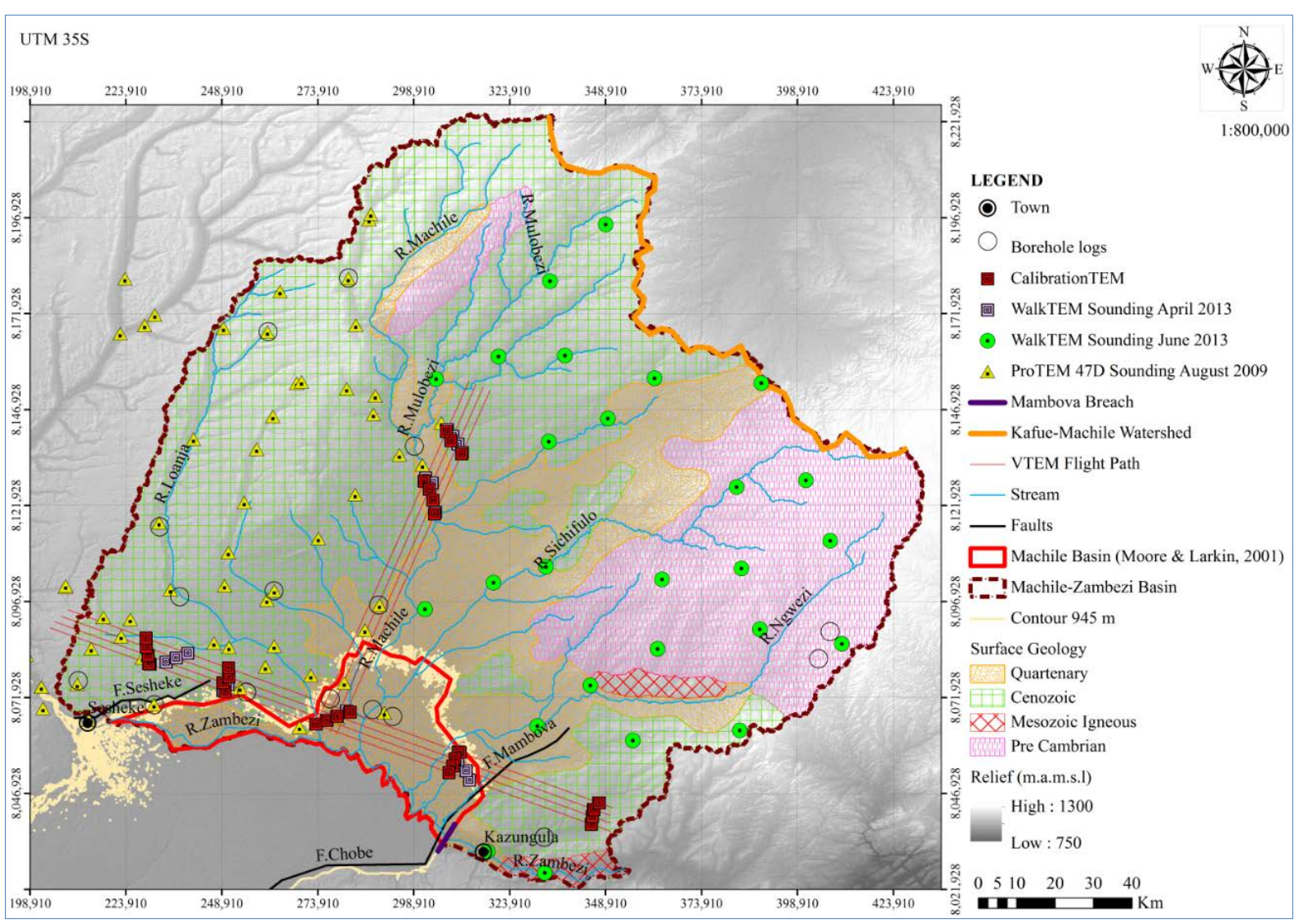

Figure 2

The study area. Shown on the map are the flight lines for the airborne survey and points where ground-based TEM measurements were conducted. Also shown on the map are points were borehole logging was conducted by Banda et al. (Technical University of Denmark/University of Zambia, Unpublished data, 2014). The surface geology is predominantly unconsolidated Cenozoic sediments with significant outcrop of the basement complex in the eastern region after Persits et al. (http://pubs.usgs.gov/of/1997/ofr-97470/OF97-470A/, 2002). Elevation data from Jarvis et al. (http://srtm.csi.cgiar.org, 2008). The outline of the Machile Basin after Moore and Larkin (2001) is also contrasted with the outline of the Machile-Zambezi Basin. 


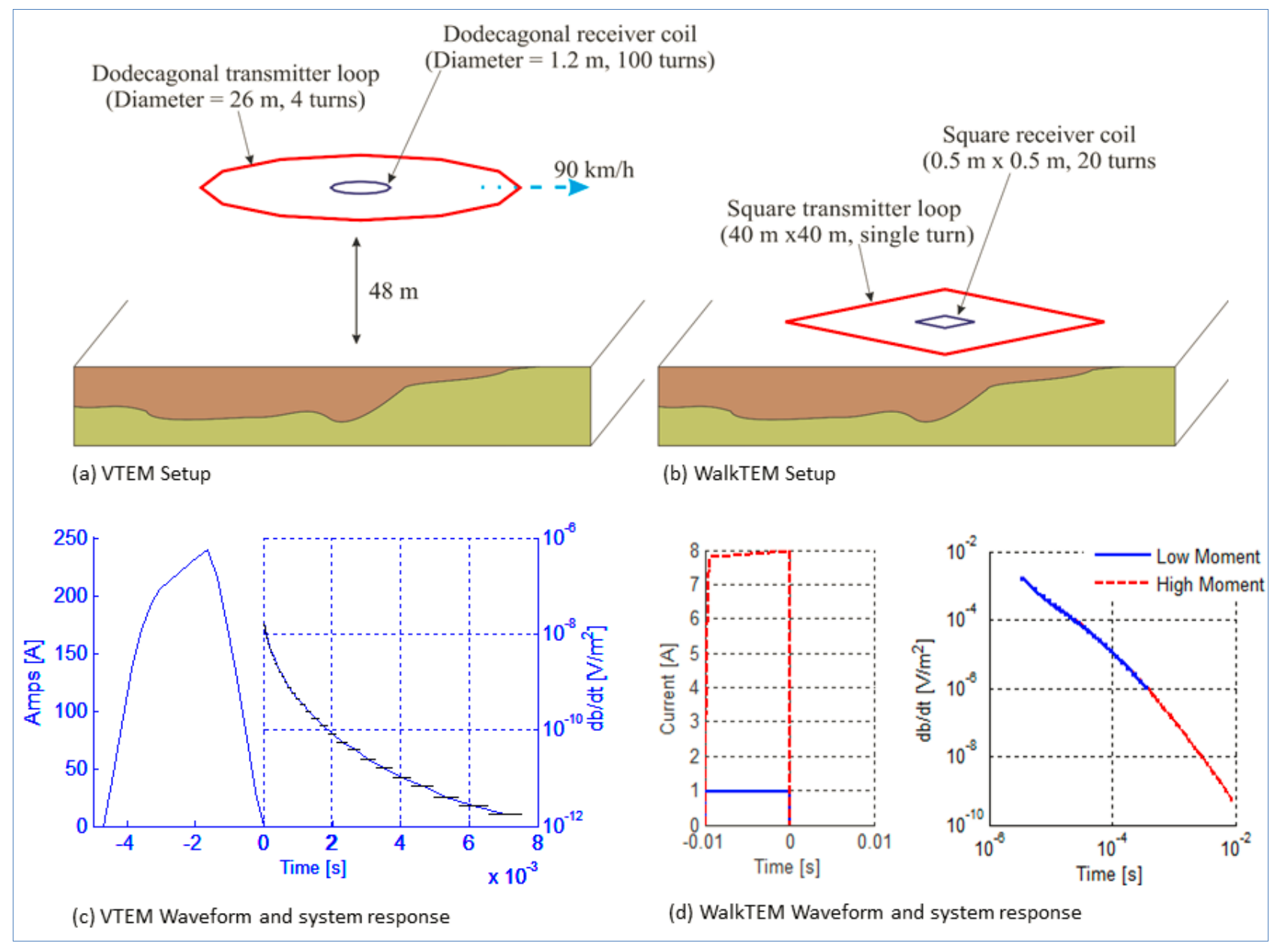

\section{$658 \quad$ Figure 3}

659 Field Schematics, transmitter waveform and system response for the WalkTEM and VTEM 660 systems: (a) VTEM Setup; (b) WalkTEM Setup; (c) VTEM waveform and system response; and (d) WalkTEM waveform and system response. 

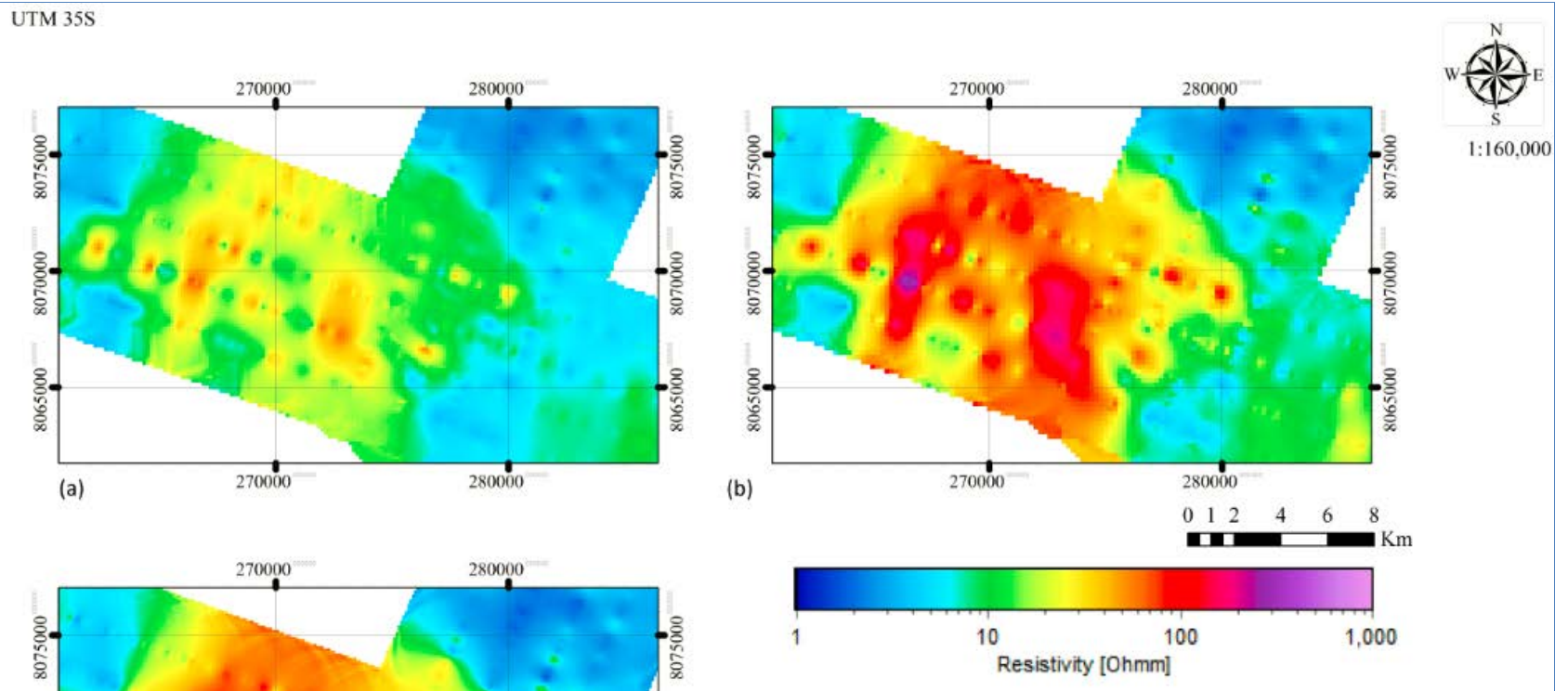

662

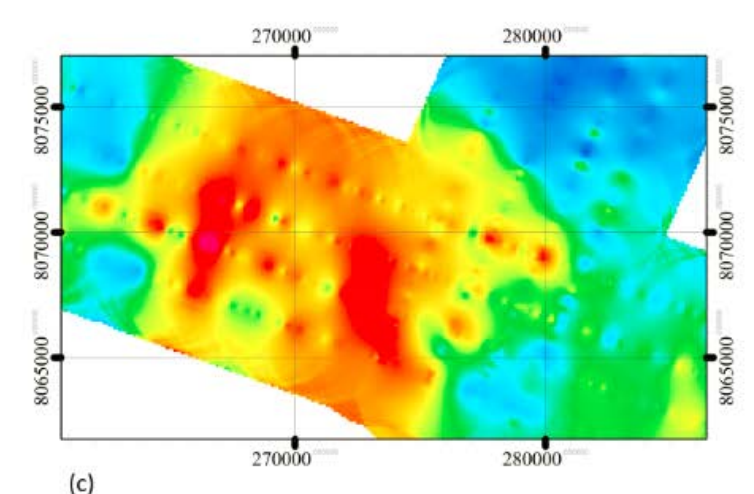

663 Figure 4

664 Comparison of horizontal resistivity thematic maps over the Loanja Alluvial Fan at depth 665 interval 0 to $20 \mathrm{~m}$ for a 29-layer smooth inversion using (a) LCI with uncalibrated data; (b) LCI with calibrated data; and (c) SCI with calibrated data. 


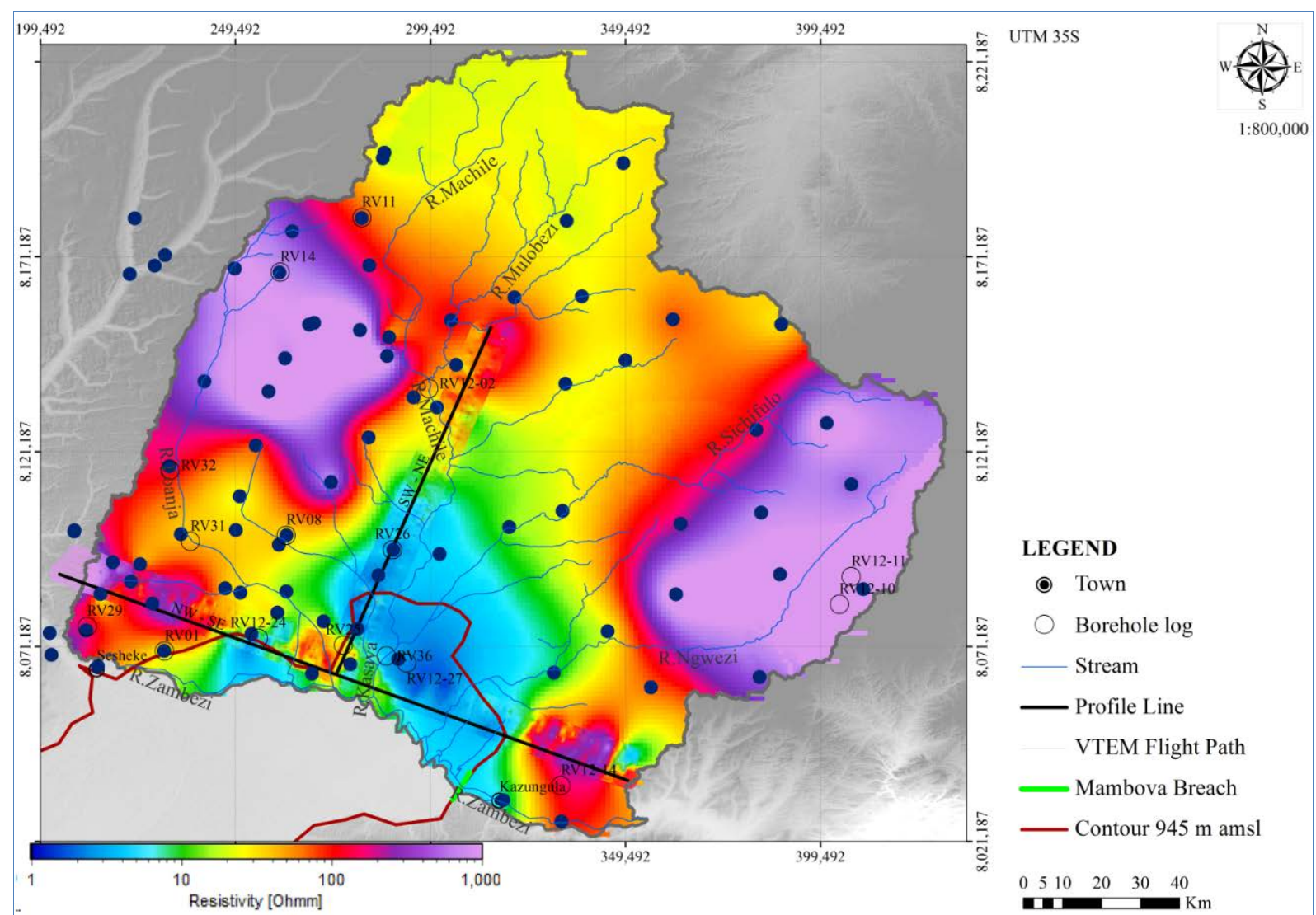

$669 \quad$ Figure 5

670 Mean horizontal electrical resistivity variations at depth interval of $0 \mathrm{~m}-20 \mathrm{~m}$. 

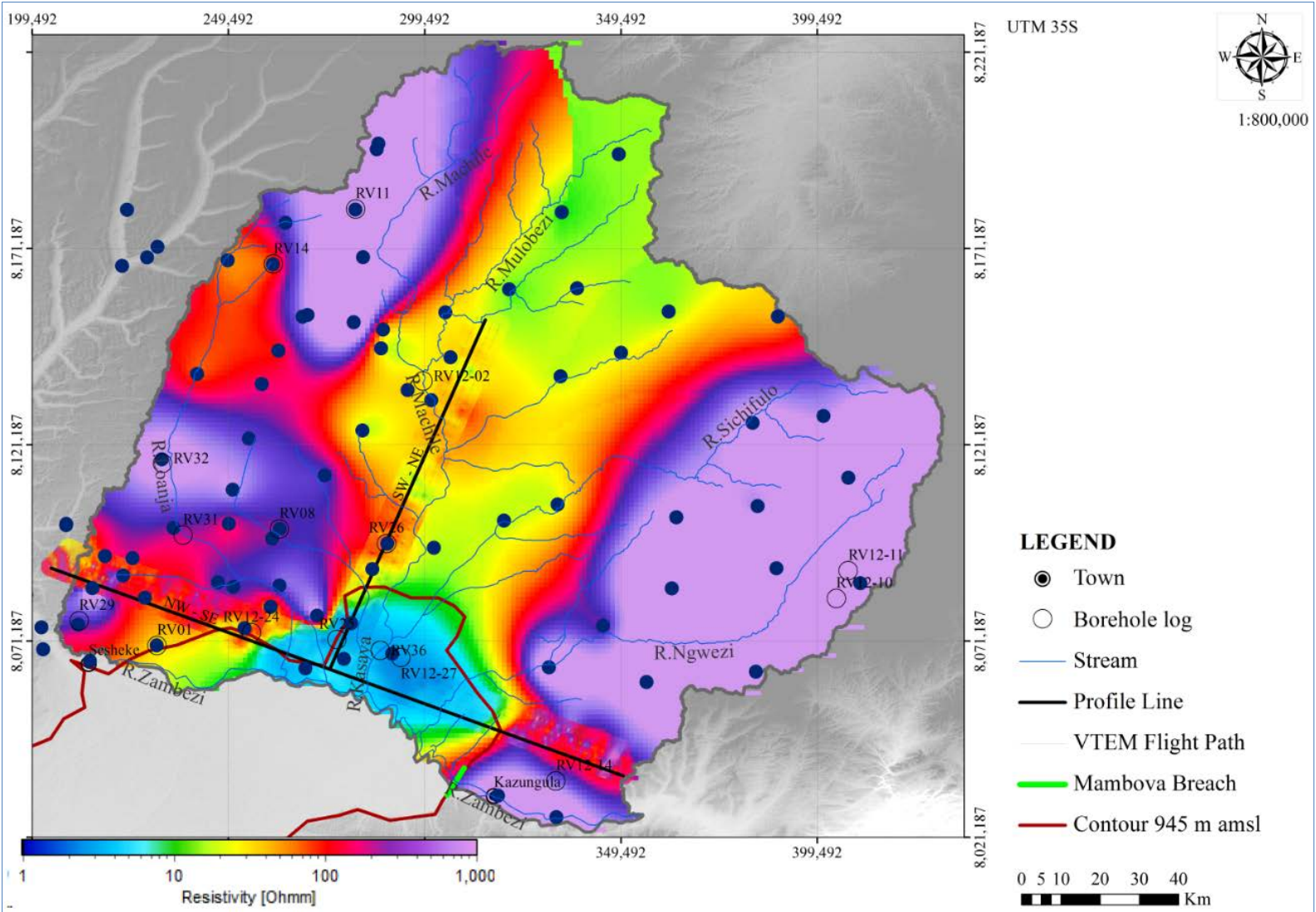

Figure 6

Mean horizontal electrical resistivity variations at depth interval $80 \mathrm{~m}-100 \mathrm{~m}$.

Figure 7

(a) Northwest to southeast cross section along profile line NW_SE (Fig. 5). (b) Southwest to northeast cross section along profile line SW-NE (Fig. 5). The depth of investigation is the top of the faded part of the electrical resistivity cross sections.

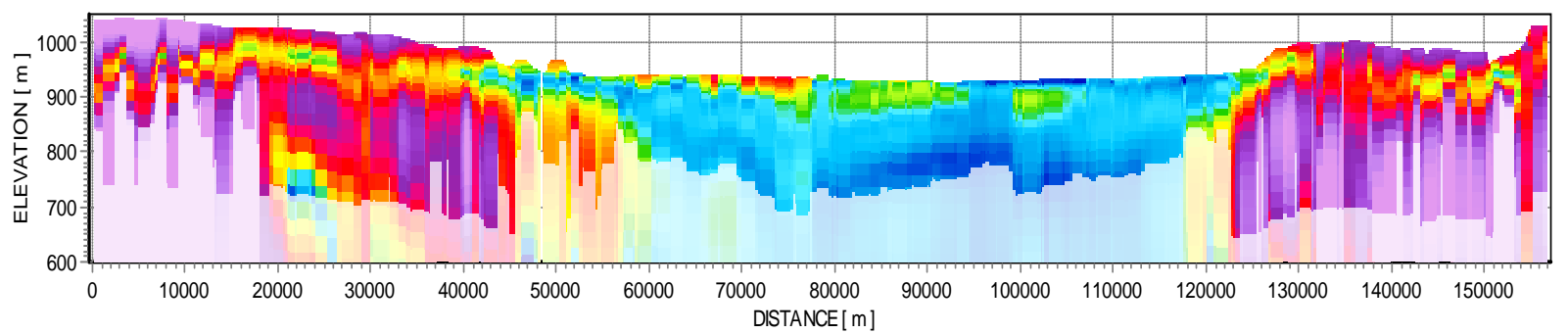

(a)

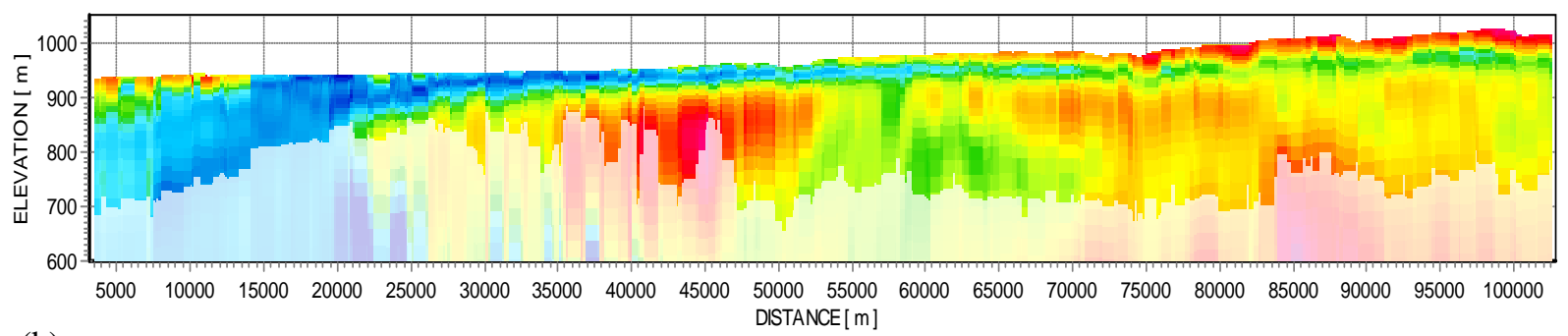

(b) 


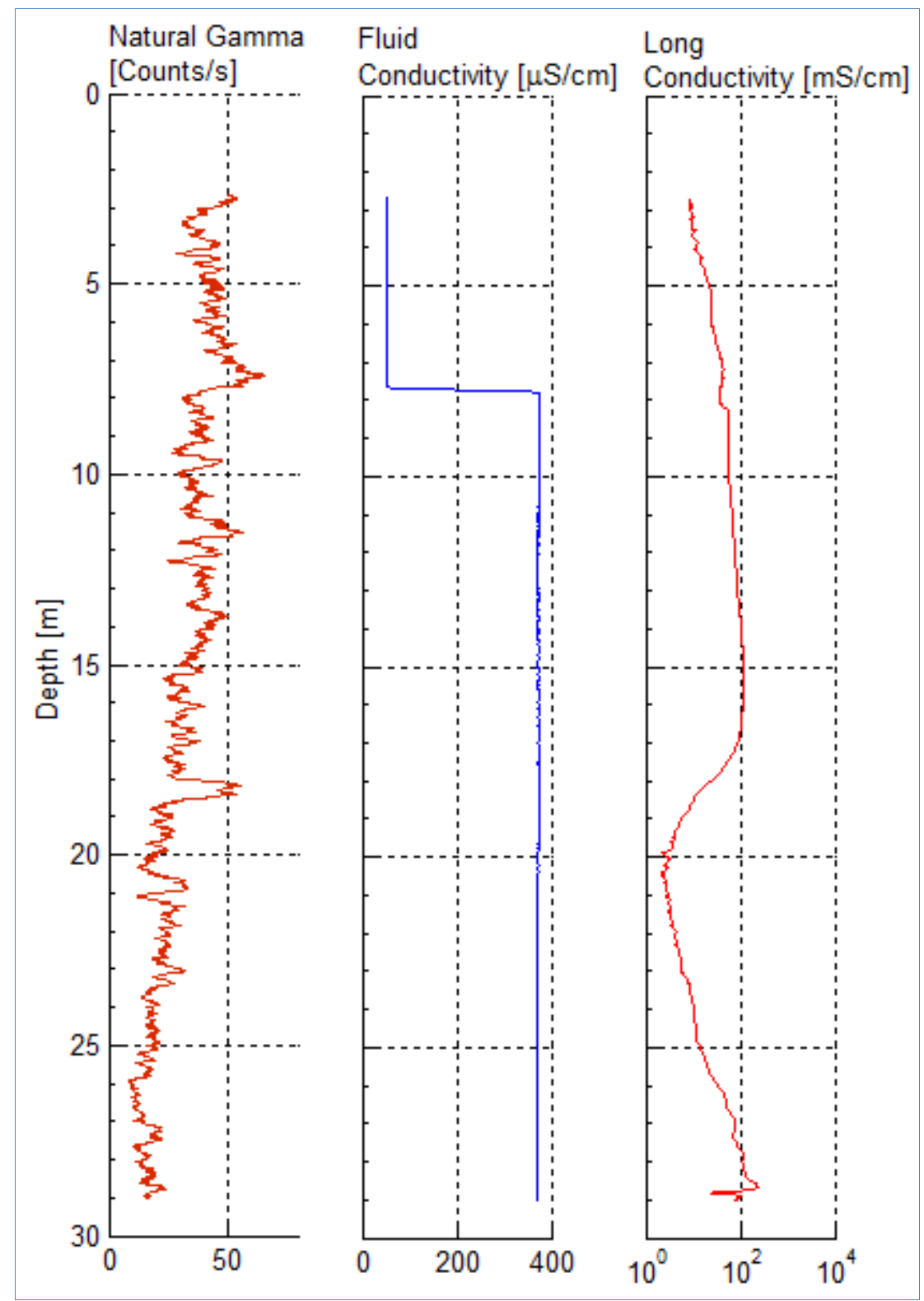

682

Figure 8

684 Example borehole log from borehole RV31.

685

686 


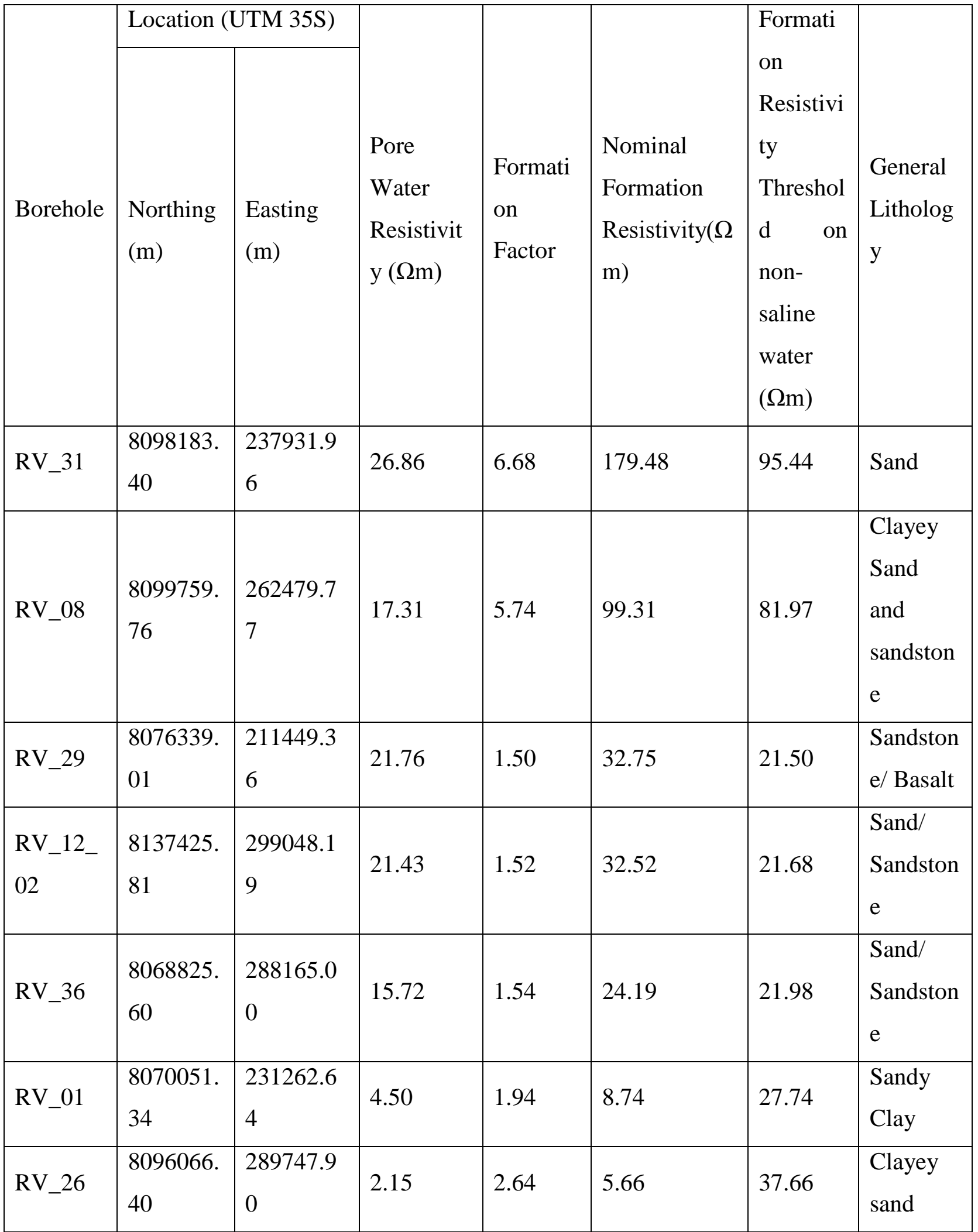


Table 2

Selected borehole records in Machile-Zambezi Basin (Kameyama 2003; Bäumle et al. 2007)

\begin{tabular}{|c|c|c|c|c|c|}
\hline \multicolumn{2}{|l|}{ Borehole 1} & \multicolumn{2}{|l|}{ Borehole 2} & \multicolumn{2}{|l|}{ Borehole 3} \\
\hline Name & Mbanga & Name & Kasaya & Name & Munyeula \\
\hline Latitude & 17.45241667 & Latitude & 17.45497222 & Latitude & 17.06072222 \\
\hline Longitude & 24.96958333 & Longitude & 25.00333333 & Longitude & 24.66130556 \\
\hline $\mathrm{EC}(\mu \mathrm{S} / \mathrm{cm})$ & 7250 & $\begin{array}{l}\text { EC } \\
(\mu \mathrm{S} / \mathrm{cm})\end{array}$ & 12180 & $\mathrm{EC}(\mu \mathrm{S} / \mathrm{cm})$ & 263 \\
\hline Depth (m) & Lithology & Depth (m) & Lithology & Depth (m) & Lithology \\
\hline 1 & Fine sand & 6 & Clay & 12 & Fine sand \\
\hline 2 & Clay & 12 & Fine sand & 18 & Sandstone \\
\hline 4 & $\begin{array}{l}\text { Clayed Fine } \\
\text { sand }\end{array}$ & 16 & $\begin{array}{l}\text { Clayed fine } \\
\text { sand }\end{array}$ & 40 & Sandstone \\
\hline 10 & Fine sand & 34 & $\begin{array}{l}\text { Clayed fine } \\
\text { sand }\end{array}$ & 52 & Sandstone \\
\hline 14 & $\begin{array}{l}\text { Clayed Fine } \\
\text { sand }\end{array}$ & 50 & Fine sand & 58 & Basalt \\
\hline 16 & Clay & 56 & $\begin{array}{l}\text { Clayed fine } \\
\text { sand }\end{array}$ & 70 & Basalt \\
\hline 22 & Medium sand & 60 & Fine sand & & \\
\hline 26 & $\begin{array}{l}\text { Clayed Fine } \\
\text { sand }\end{array}$ & 62 & $\begin{array}{l}\text { Clayed fine } \\
\text { sand }\end{array}$ & & \\
\hline 66 & Fine sand & 82 & Fine sand & & \\
\hline \multicolumn{2}{|l|}{ Borehole 4} & \multicolumn{2}{|l|}{ Borehole 5} & \multicolumn{2}{|l|}{ Borehole 6} \\
\hline Name & Siamundele & Name & Sekute School & Name & Kamenyani \\
\hline Latitude & -17.17558 & Latitude & -17.65472 & Latitude & 17.06680556 \\
\hline Longitude & 25.83619 & Longitude & 25.65889 & Longitude & 25.16697222 \\
\hline $\mathrm{EC}(\mu \mathrm{S} / \mathrm{cm})$ & - & $\begin{array}{l}\text { EC } \\
(\mu \mathrm{S} / \mathrm{cm})\end{array}$ & - & $\mathrm{EC}(\mu \mathrm{S} / \mathrm{cm})$ & 1932 \\
\hline Depth (m) & Lithology & Depth (m) & Lithology & Depth (m) & Lithology \\
\hline 2 & Top soil & 6 & $\begin{array}{l}\text { Sand with } \\
\text { clay }\end{array}$ & 4 & Fine sand \\
\hline 28 & Granite & 18 & Sandstone & 6 & Clay \\
\hline
\end{tabular}




\begin{tabular}{|l|l|l|l|l|l|}
38 & Granite & 49 & Basalt & 22 & $\begin{array}{l}\text { Fine sand }+ \\
\text { silt }\end{array}$ \\
\hline 66 & Granite & & & 36 & Sandstone \\
\hline & & 55 & Quartz \\
\cline { 4 - 5 } & & 68 & Sandstone \\
\hline
\end{tabular}

700

701 